\title{
Investigation of scientific creativity levels of elementary school students who enrolled in a STEM program ${ }^{1-2}$
}

\author{
Selvet Ece Genek, Istanbul Medipol University, Turkey, ecegenekk@gmail.com \\ ORCID: 0000-0002-2224-5266 \\ Zerrin Doğança Küçük, Maynooth University-National University of Ireland, Ireland, \\ zerrin.dogancakucuk@mu.ie ORCID: 0000-0002-4439-3825
}

\begin{abstract}
This study aims to evaluate the scientific creativity levels of second, third and fourth grade students who enrolled in a STEM course for an entire academic year. The sample consisted of 85 elementary school students in two private schools in Antalya, Turkey. "Scientific Creativity Test" and "Student Demographic Questionnaire" were the instruments used in the study. Findings revealed that the scientific creativity level of the students showed a statistically significant difference with respect to their grade level. No significant differences were observed based for other variables (gender, number of siblings, parental occupation, favorite subject, the most successful subject, future occupation). In this paper, selected student responses will be presented together with a comparison of the existing curricula and the implemented STEM curriculum as well as a discussion of the findings. The study has indicated that the implemented STEM program positively affected scientific creativity of the students.
\end{abstract}

Keywords: STEM education, scientific creativity, elementary education

Received: 16.05 .2019

Accepted: 26.02 .2020

Published: 15.06 .2020

\section{INTRODUCTION}

In a world with highly complex and nested problems, the static structure of educational systems results in students lacking interest in the conceptualization of global problems. Conventional educational approaches cause the new generation to be even more reluctant to find unique solutions and products for real-world problems (Sanders, 2009). 21st century comes with the need to design new products through integration of scientific knowledge from different disciplines. Accordingly, technological applications and engineering practices have to be integrated into the existing mathematics and science curricula (Kennedy \& Odell, 2014). Technological developments in the $21^{\text {st }}$ century oblige individuals to acquire new skills and develop the skills they already have. Recent technological innovations have made it easier to access information; with this, however, source and accuracy of knowledge has started to be of greater importance. For educators, managing students' easy access to information seems to be a challenge. Therefore, it is necessary for students to acquire the $21^{\text {st }}$ century skills in such a way that they can synthesize the existing knowledge about phenomena and come up with end products using their existing scientific knowledge (Yavuz \& Coşkun, 2008).

The flaws in the current educational system and new requirements of the $21^{\text {st }}$ century that have to be met to successfully deal with the considerably few number of students who are interested in STEM fields and are willing to pursue careers in STEM disciplines in US, as well as the high number of middle and high school graduates with excessively low science and mathematics abilities (Sanders, 2009), have made integrative STEM (Science, Technology, Engineering, and Mathematics) education even more crucial. The integrative approach to STEM education involves integration of at least two STEM disciplines by taking the interests and experiences of both students and the teacher into account while maintaining the central focus of the discipline taught (Çorlu, Capraro, \& Çorlu, 2015). STEM education aims to motivate learners

\footnotetext{
${ }^{1}{ }_{1}$ This paper has been produced from the master thesis titled “STEM Programı Uygulanan İlkokul Öğrencilerinin Bilimsel Yaratıcıllk Düzeylerinin İncelenmesi".

${ }^{2}$ This paper was partially presented at the XIII. National Science and Mathematics Education Congress, Denizli, Turkey.
} 
to work on real-world problems by generating ideas and designing relevant products based on integrated STEM knowledge and STEM skills (Rinke, Gladstone-Brown, Kinlaw, \& Cappiello, 2016).

Next Generation Science Standards (NGSS, 2013) consider the two important themes of STEM education to be "innovation" and "creativity". The need for innovative solutions to complex global problems and exposure of the young generation to experience-rich instructional activities through research, ideation, testing, and reflection should be by met today's societies to nourish children's creativity.

\section{Creativity and Scientific Creativity}

\section{Creativity}

Creativity is more than an innate personality trait commonly associated with artists and those that are gifted (Ülger, 2014). From a cognitive point of view, creativity is a feature of mind rather than a special attribute. As Roberts puts it (2003), if an individual engages in a higher number of activities nourishing creativity, s/he can improve his or her own creativity. There are both individual and social aspects to creativity. Individuals generating alternative ideas to nonroutine real-life problems and societies engaging in inventions, innovations, and works of art are all products of creative thinking (Kanl, 2017).

Global economies need original products with innovative features, and creative individuals are in higher demand than ever before in both academic and professional settings. Baykal (2008) defines individuals with high creative thinking skills as those who are capable of leading innovations and making any kind of adaptations in every aspect of social life. Çorlu (2017) stresses the importance of creative, inquisitive, and productive individuals that will lead transition into a knowledge society. This is possible only when the education system supports development of creative and critical thinking. Rinke and her colleagues (2006) emphasize the indispensable role of teachers as agents that will integrate activities and content relevant to the development of creative thinking skills into their classes, and that have the potential to support students' personal development and career pursuits.

\section{Scientific Creativity}

Research on creativity has revealed that creativity is domain-specific (Feldman, 1994; Runco, 1989 ) in the sense that individuals perform different levels of creativity in tasks on different subject matters (Baer, 1998; Han, 2000). Alexander (1992) and Amabile (1987) emphasize the need to distinguish between creativity and scientific creativity. This is because scientific creativity is activated only when we encounter problems (Aktamış \& Ergin, 2006).

Scientific creativity is the whole set of higher order thinking skills with important effects on the individual's tendency to be mentally flexible and open to innovation. It has absolute relevance to scientific knowledge, skills and attitudes (Demir, 2015). Ceran, Güngören, and Boyacıoğlu (2014) define scientific creativity as the ability to develop original ideas or methods and design original products.

Creativity appears to be a major competency in the Science Curriculum (Ministry of National Education [MoNE], 2018), although the term scientific creativity has not been integrated in the curriculum yet. Aktamış and Ergin (2006) criticize conventional science education in schools where scientific concepts and theories are taught directly and by means of highly structured activities and experiments with strict instructions for the presented scientific concepts or theories to be tested in a reliable way. In contrast, inquiry-based experiments with open-ended tasks, which enable students to test their own hypotheses, will support development of both their scientific creativity (Aktamış \& Ergin, 2006) and science process skills (Aktamış \& Ergin, 2007).

\section{Significance of the Study}

Recent educational approaches concentrate on the development of higher order thinking skills, which is a key component of both STEM education practices and $21^{\text {st }}$ century skills. In the literature, one can see an increasing number of studies on STEM education (Breiner, Harkness, 
Johnson, \& Koehler, 2012; Bybee, 2010; Sanders, 2009) and scientific creativity (Çeliker ve Balım, 2012; Hu \& Adey, 2002). However, no previous research on scientific creativity and STEM education was available when this study was carried out. Besides, studies on STEM education (Baran, Canbazoğlu-Bilici \& Mesutoglu, 2017; Becker \& Park, 2011; Brody, 2006; Ricks, 2006; Hiller, \& Kitsantas, 2014; Sadler, Sonnert, Hazari,\& Tai, 2012; Stohlmann, Stohlmann, Moore, \& Roehrig, 2012; Tyson, Borman, \& Hanson, 2007) and scientific creativity (Aktamış \& Ergin, 2007; Ayverdi, Asker, Öz Aydın, Sarıtaş, 2012; Kanlı, 2017; Kılıç \& Tezel, 2012; Lin, Hu, Adey, \& Shen, 2003; Pekmez, Aktamış, \& Taşkın, 2009) generally focus on middle and high school students. Therefore, this paper attempts to investigate scientific creativity levels of elementary school students who go through a one-year long STEM program.

\section{METHOD}

\section{Research Design}

In this study, a descriptive quantitative research design was used. For the purposes of this study, the instruments were administered to the sample at the end of the 2016-2017 academic year, when the students were already exposed to the elementary STEM program.

\section{Sample}

The universe of this study constitutes students from ten elementary private schools functioning in six different cities in Turkey, where EarlySTEM program was implemented throughout the 2016-2017 Academic Year. The sample consisted of 85 second, third, and fourth grade students from two different private elementary schools in Antalya, Turkey. Gender distribution of the sample across grade levels can be seen in Table 1.

Table 1. Distribution of student gender across grade levels

\begin{tabular}{lccc}
\hline Grade & Female Students & Male Students & Total \\
\hline 2nd & 17 & 18 & 35 \\
3rd & 17 & 12 & 29 \\
4th & 7 & 14 & 21 \\
Total & 41 & 44 & 85 \\
\hline
\end{tabular}

For practical reasons, convenient sampling was used and student data was collected from two schools in Antalya, Turkey. The EarlySTEM program was implemented to K-4 students; however preschool and first grade students were eliminated from the study as they were illiterate.

\section{Instruments}

Scientific Creativity Test (SCT) and demographic information sheet were used as instruments in this study. In line with the research questions, Demographic Information Sheet was used to gather personal information on participants' favorite school subjects, future occupation, and parental occupation.

Scientific Creativity Test (SCT) was developed by Hu and Adey (2002). SCT is a wellknown test that aims to measure scientific creativity of middle school students (12-15 yearolds). The test was administered in a number of studies (Baysal, Kaya, \& Üçüncü, 2013; Ayverdi et. al., 2012; Kılıç \& Tezel, 2012; Lin et. al., 2003). In this study, Turkish adaptation of SCT by Çeliker and Balım (2012) was used. 
Table 2. Targeted skills of scientific creativity test questions

\begin{tabular}{|c|c|c|c|}
\hline Item (question) number & Targeted skills & Dimension & Score \\
\hline $\begin{array}{l}\text { 1. Please write down as many } \\
\text { possible scientific uses of a piece } \\
\text { of glass as you can. }\end{array}$ & $\begin{array}{l}\text { Using an object for } \\
\text { scientific purposes }\end{array}$ & Originality & $\begin{array}{l}>\% 10,0 \text { point } \\
\% 5-\% 10,1 \text { point } \\
<\% 5,2 \text { point }\end{array}$ \\
\hline $\begin{array}{l}\text { 2. If you could take a spaceship } \\
\text { to travel in the outer space and } \\
\text { go to a planet, what scientific } \\
\text { questions would you like to } \\
\text { investigate? Please list as many } \\
\text { as you can. }\end{array}$ & $\begin{array}{l}\text { Sensitivity to science } \\
\text { problems }\end{array}$ & Flexibility & $\begin{array}{l}1 \text { point for each } \\
\text { alternative approach }\end{array}$ \\
\hline $\begin{array}{l}\text { 3. Please think of as many } \\
\text { possible improvements to be } \\
\text { made to a regular bicycle as you } \\
\text { can, that will make it more } \\
\text { interesting, more useful and } \\
\text { more beautiful. }\end{array}$ & $\begin{array}{l}\text { Technical product } \\
\text { development }\end{array}$ & Fluency & $\begin{array}{l}1 \text { point for each } \\
\text { response }\end{array}$ \\
\hline
\end{tabular}

\section{Suppose there was no gravity. Describe what the Earth would be like? \\ Scientific imagination}

\begin{tabular}{|c|c|c|c|}
\hline $\begin{array}{l}\text { 5. Please use as many possible } \\
\text { methods as you can to divide a } \\
\text { square into four equal pieces } \\
\text { (same shape). Draw it on the } \\
\text { answer sheet. }\end{array}$ & $\begin{array}{l}\text { Solving a science } \\
\text { problem }\end{array}$ & Flexibility & $\begin{array}{l}1 \text { point for each } \\
\text { alternative approach }\end{array}$ \\
\hline $\begin{array}{l}\text { 6. There are two kinds of } \\
\text { napkins. How can you test } \\
\text { which is better? Please write } \\
\text { down as many possible methods } \\
\text { as you can and the instruments, } \\
\text { principles and a simple } \\
\text { procedure. }\end{array}$ & $\begin{array}{l}\text { Creative experimental } \\
\text { ability }\end{array}$ & Originality & $\begin{array}{l}>\% 10,0 \text { point } \\
\% 5-\% 10,1 \text { point } \\
<\% 5,2 \text { point }\end{array}$ \\
\hline $\begin{array}{l}\text { 7. Please design an apple picking } \\
\text { machine. Draw a picture, point } \\
\text { out the name and function of } \\
\text { each part. }\end{array}$ & $\begin{array}{l}\text { Creative science } \\
\text { product design ability }\end{array}$ & Originality & $\begin{array}{l}\text { 0: The machine does } \\
\text { not collect apples. } \\
\text { 1: Collecting with } \\
\text { mechanic hand or } \\
\text { collecting just the } \\
\text { apples that fall. } \\
\text { 2: Collecting with } \\
\text { vacuum. } \\
\text { 3: One distinctive } \\
\text { original function } \\
\text { 4: More than one } \\
\text { distinctive original } \\
\text { function. } \\
\text { 5: Original collection } \\
\text { method } \\
3 \text { points for each } \\
\text { alternative function }\end{array}$ \\
\hline
\end{tabular}

SCT gained recognition as a prominent test developed on a conceptual model (Kanl, 2017) called the Scientific Structure Creativity Model. The three-dimensional model incorporates three 
of the four dimensions of creative thinking defined by Torrance (1990) as traits of scientific creativity, while the other two dimensions are closely linked to production and processing of scientific creativity (Hu \& Adey, 2002). SCT is made up of seven open-ended questions aiming to measure level of a variety of target scientific skills. Table 2 presents SCT questions, target scientific skills, dimensions and scoring procedure suggested by Hu and Adey (2002).

$\mathrm{Hu}$ and Adey (2002) calculated reliability coefficient of SCT as .89. Turkish translation of the scale was calculated as .86 (Çeliker \& Balım, 2012). The reliability coefficient was found to be .69 for the elementary school students who participated in the study. In addition to calculating the reliability coefficient, the two researchers also evaluated all the STC questions individually with a range of $90-100 \%$ agreement percentage. Subsequently, collaborative analysis of the questions was carried out, leading to a consensus on how to score individual student responses.

\section{Early STEM Program}

At the beginning of the 2016-2017 Academic Year, 30 pre-school and class teachers, in collaboration with two academicians, planned the "early STEM Program" in detail. The program development group designed weekly plans for K-4 grades (Doğança Küçük, 2017). The program was implemented at 10 schools in six different cities in Turkey. One class hour was devoted each week to the implementation of the program.

Early STEM program was derived from STEM: Integrated Teaching Framework (Çorlu, 2017), with four themes each centering on one STEM discipline and ensuring integration at the same time into other STEM disciplines (Figure 1). Four additional principles of Integrated Teaching were presented in the framework as well. Here, Equity and relevance refer to the representation of student's own life experiences and areas of interest at school, while interdisciplinary nature and rigor are concerned with the integration of the disciplines within the framework and presentation and implementation of relevant and rigorous information and skills involved in the central STEM discipline, respectively. The outer layer of the framework represents overall objectives of STEM education, which are identified as "developing a knowledge-society", "implementation of a flexible curriculum by teachers", "formation of a professional learning community of teachers", and "improvement of STEM education theories and practices by researchers". "Authentic problem of knowledge society" (APKS) lies at the center of the framework. APKS is an open-ended dynamic $21^{\text {st }}$ century problem that could be solved by means of alternative strategies considering the limitations presented (Așlk et al. 2017).

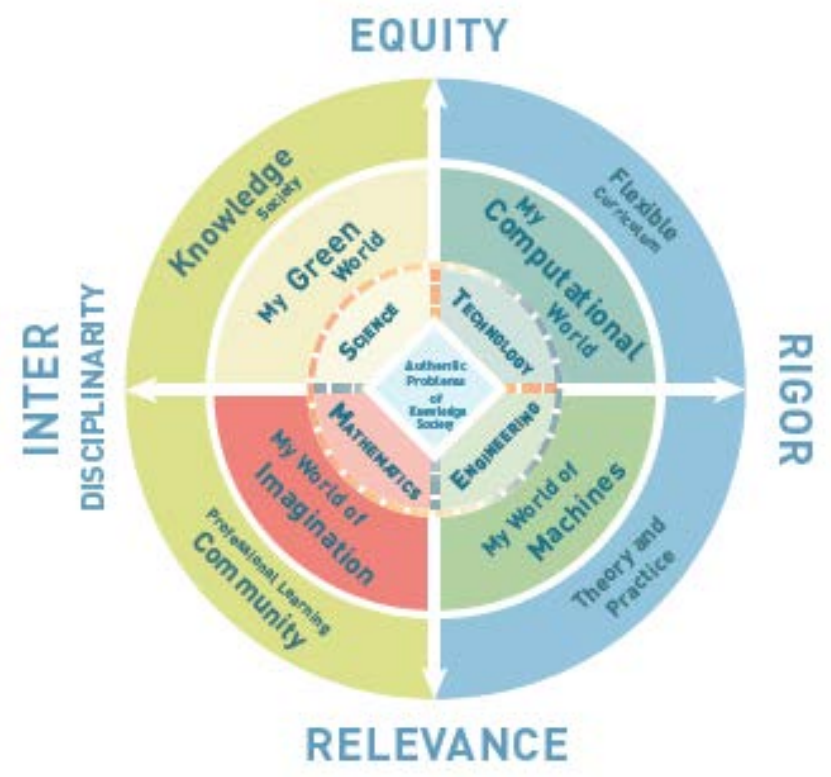

FIGURE 1. Integrated Teaching Framework for early STEM Program

While planning the Early STEM themes, it was assumed that every eight-week time interval 
should involve the same cognitive processes and planning steps. Each theme was designed in accordance with the STEM Cycline (Figure 2), which is based on the Integrated Teaching Framework (Çorlu, 2017). The STEM Cycline consists of stages where,

a) APKS is presented with various attractive visuals by means of incorporation of a number instructional techniques,

b) Students search for the answers to the open-ended fact-finding questions presented by the teacher,

c) Students generate and select ideas by considering the limitations presented in APKS

d) Students develop their products as an alternative solution to APKS,

e) Students test their products for the limitations

f) Students present their products together with an explanation of production processes and evaluations in various formats (Doğança Küçük, 2017).

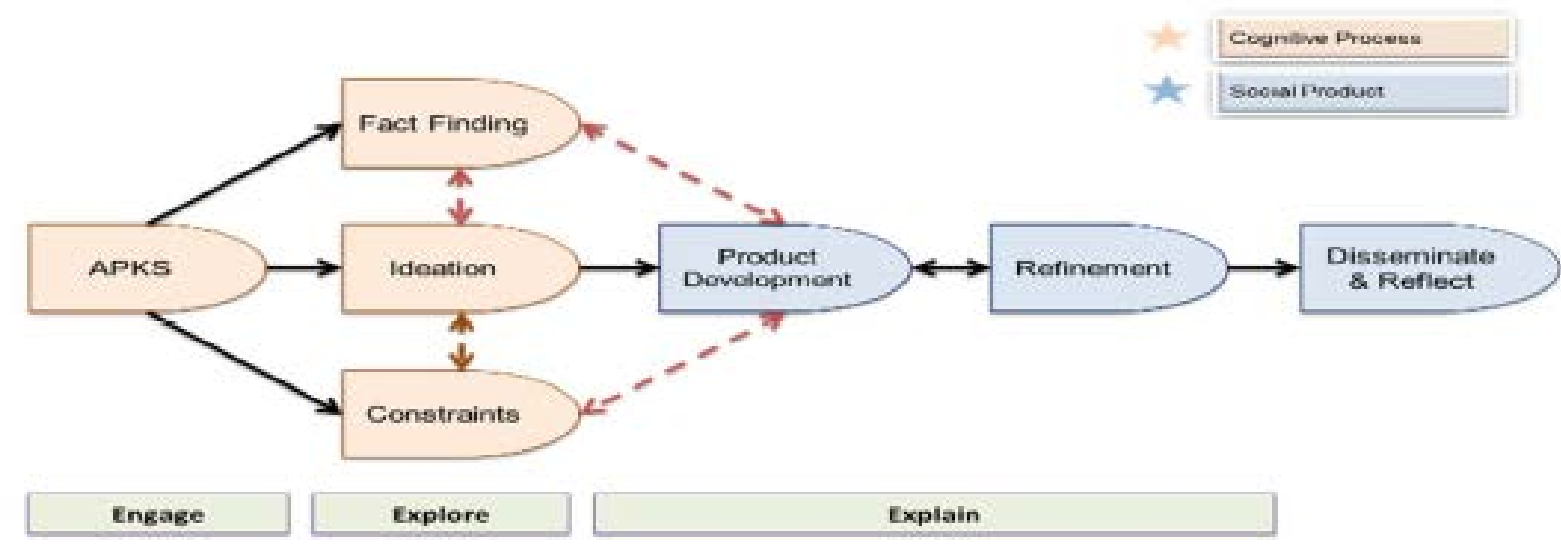

FIGURE 2. STEM Cycline to represent ITP STEM lesson plan model

\section{RESULTS}

\section{Demographic Data}

Demographic data was collected using the Demographic Information Sheet. Along with the gender and grade distribution presented in Table 1, data regarding the number of their siblings was obtained. It was found that majority of the students had either one sibling $(n=38 ; 44.7 \%)$ or no siblings at all $(n=25 ; 29.4 \%)$, unlike a few others with more than one sibling $(n=22 ; 25.9 \%)$.

In the Demographic Information Sheet, there were four questions whose responses were categorized as either STEM or non-STEM. The first two questions were on students' favourite subjects(s) and the subject(s) they were most successful at. Life sciences taught at second grade was considered to be a STEM course as well for its scientific content. It was found that $78.8 \%$ $(n=67)$ of the students identified their favourite subjects as the STEM category, while only $21.2 \%$ $(n=18)$ of the students expressed their interest in non-STEM courses. Similarly, 74.1\% $(n=63)$ of the students stated that subjects they were most successful at were those that belong to the STEM category, whereas $25.9 \%$ of the students $(n=22)$ perceived courses categorized as nonSTEM as their most successful fields. The students were also asked about their future occupations as well as their parents' occupation. While answering the question regarding parental profession, if one parent worked at a STEM-related field, students responded in a way favoring the STEM category. For both questions, the majority of the responses were found to be favoring STEM related occupations as shown in Table 3. 
Table 3. Student responses for the STEM -related questions on the demographic information sheet

\begin{tabular}{lcccc}
\hline Demographic Questions & \multicolumn{2}{c}{ STEM } & \multicolumn{2}{c}{ Non-STEM } \\
\hline & Frequency & Percentage & Frequency & Percentage \\
\cline { 2 - 5 } Favourite Subject(s) & 67 & 78.8 & 18 & 21.2 \\
The Most Successful Subjec(s) & 63 & 74.1 & 22 & 25.9 \\
Future Occupation & 58 & 68.2 & 27 & 31.8 \\
Parental Occupation & 68 & 80 & 17 & 20 \\
\hline
\end{tabular}

\section{Descriptive Statistics}

Descriptive measures of student responses to SCT are presented below. Table 4 shows basic descriptive statistics, namely mean, standard value, minimum and maximum of SCT scores with respect to grade level.

Table 4. Descriptive statistics of STC scores

\begin{tabular}{cccccc}
\hline Grade & Mean & N & SD & Minimum & Maximum \\
\hline 2 & 23.11 & 35 & 11.68 & 5 & 58 \\
3 & 29.63 & 30 & 9.29 & 8 & 49 \\
4 & 37.65 & 20 & 10.86 & 18 & 57 \\
\hline Overall & 28.84 & 85 & 12.00 & 5 & 58 \\
\hline
\end{tabular}

In Tables 5-10, student responses are presented with their frequencies and percentages. It should be noted that there were some unconventional and irrelevant responses as well. The unconventional responses with the highest number with respect to originality are listed below in the corresponding table.

Table 5. Frequency and percentage table for responses to Question number 1 (i.e. scientific uses of glass)

\begin{tabular}{|c|c|c|}
\hline Student responses & Frequency & Percentage \\
\hline Lighting a fire & 14 & 12.0 \\
\hline Kitchen stuff (cups, plates, jars, knives etc.) & 14 & 12.0 \\
\hline Household items (table, vase, frame, trash can, aquarium etc.) & 13 & 11.1 \\
\hline Eyeglass-lens & 9 & 7.7 \\
\hline Mirror & 9 & 7.7 \\
\hline Windows (house) & 8 & 6.8 \\
\hline Accessories (bracelet, necklace, keychain etc.) & 7 & 6.0 \\
\hline $\begin{array}{l}\text { Tools for changing the size of an image (binoculars, magnifying } \\
\text { glasses, microscopes) }\end{array}$ & 6 & 5.2 \\
\hline Light Bulb & 5 & 4.3 \\
\hline Clock and car glass & 4 & 3.4 \\
\hline Monitor (phone, tablet) & 4 & 3.4 \\
\hline Reflecting light & 4 & 3.4 \\
\hline Melting for reuse & 3 & 2.6 \\
\hline Smart board & 2 & 1.7 \\
\hline
\end{tabular}

The unconventional responses for Question number 1 were stirring rods, pendulum, water 
bottle, rocket, laser, botanical garden capsule, surface for refrigerators, and a cover for a space shuttle engine. Four students said 'toy' as answer to this question and the response was considered irrelevant.

Table 6. Frequency and percentage table for responses to Question number 2 (i.e. scientific questions when exploring the space)

\begin{tabular}{|c|c|c|}
\hline Student responses & Frequncy & Percentage \\
\hline Existence of life on the planet? & 31 & 17.5 \\
\hline The amount of water on the planet & 17 & 9.9 \\
\hline $\begin{array}{l}\text { Life on the planet (human, animal, plant, and other life } \\
\text { forms) }\end{array}$ & 14 & 8.2 \\
\hline Aliens & 12 & 7.0 \\
\hline Travelling to the planet & 12 & 7.0 \\
\hline Questions about the universe (galaxy, milky way, ...) & 8 & 5.7 \\
\hline The position of the planet & 7 & 4.1 \\
\hline Questions about the world & 5 & 2.9 \\
\hline Colors & 5 & 2.9 \\
\hline Physical features of the planet (surface, shape etc.) & 5 & 2.9 \\
\hline Gravity & 5 & 2.9 \\
\hline Temperature on the planet & 5 & 2.9 \\
\hline The name of the planet & 5 & 2.9 \\
\hline Nutrition on the planet & 4 & 2.3 \\
\hline The amount of gas on the planet (oxygen / iron oxide) & 3 & 1.7 \\
\hline Dimensions of the planet & 3 & 1.7 \\
\hline Availability of food on the planet & 3 & 1.7 \\
\hline Saturn's ring & 2 & 1.2 \\
\hline Stars & 2 & 1.2 \\
\hline Getting into space & 2 & 1.2 \\
\hline Meeting with the family on the planet & 2 & 1.2 \\
\hline Breathing on the planet & 2 & 1.2 \\
\hline Comparison of Mars and the Earth & 2 & 1.2 \\
\hline
\end{tabular}

For Question number 2, 172 scientific questions were written by the students. Of all the responses, the original ones were associated with danger on the planet, existence of satellites for each planet, the ability to touch the stars and the Moon, existence of life on the satellite, fun on the planet, and room in the space. 
Table 7. Frequency and percentage table of responses to Question number 3 (i.e. improvements for a bicycle)

\begin{tabular}{lcc}
\hline Student responses & Frequency & Percentage \\
\hline Accelerator spare parts (engine, jet, rocket) & 25 & 23.6 \\
Flying bike & 20 & 18.9 \\
Comfort-entertainment (water bottle, luggage, helmets, etc.) & 17 & 16.1 \\
Insertion of accessories and spare parts (wheel, torch, sensor, pedal, & 15 & 14.1 \\
mirror, door, glass, automatic driver) & 4 & 3.8 \\
Modification (thick-thin wheel, light pedal) & 3 & 2.8 \\
Electric bike & 2 & 0.9 \\
Floating bike & 2 & 0.9 \\
Ecological bike (solar energy, generation of electricity) & 2 \\
\hline
\end{tabular}

For Question number 3, 16 students mentioned painting and/or decorating the bicycle; however this response was evaluated as irrelevant by the raters. One student came up with the idea of elimination of pedal, which was considered original due to its rare frequency.

Table 8. Frequency and percentage table for responses to Question number 4 (i.e. possible scenarios in case of no gravity)

\begin{tabular}{lcc}
\hline Student responses & Frequency & Percentage \\
\hline Everything/everybody would fly & 49 & 39.2 \\
Chaos / bad things, incidents & 38 & 30.4 \\
We would not eat / drink & 12 & 9.6 \\
Body position (sitting in the air, lying down, fall) & 11 & 8.8 \\
Directly flying to space & 3 & 2.4 \\
No excrion & 2 & 1.6 \\
Difficulty breathing & 2 & 1.6 \\
\hline
\end{tabular}

The unconventional responses for the" no-gravity" question were as follows: 'the Earth would resemble the Moon. 'There would be no sea.' 'When we cried, our tears would stay in the air.' 'We would not be able to move fast.'. The response 'We could handle our works with ease.' was rated as 0 as it lacked clarity.

Table 9. Frequency and percentage table for responses to Question number 5 (i.e. methods to divide a square into four equal pieces)

\begin{tabular}{cccccc}
\hline & No answer & $\begin{array}{c}\text { One } \\
\text { Correct } \\
\text { Answer }\end{array}$ & $\begin{array}{c}\text { Two } \\
\text { Correct } \\
\text { Answer }\end{array}$ & $\begin{array}{c}\text { Three } \\
\text { Correct } \\
\text { Answer }\end{array}$ & $\begin{array}{c}\text { Four } \\
\text { Correct } \\
\text { Answer }\end{array}$ \\
\hline Number of Students & 12 & 33 & 26 & 3 & 9 \\
\hline
\end{tabular}

In the 77 responses received, students were able to construct at most four methods to divide a square into four equal pieces from among eight possible methods. 
Table 10. Frequency and percentage table for responses to Question number 6 (i.e. testing methods for napkin quality)

\begin{tabular}{lcc}
\hline Student responses & Frequency & Percentage \\
\hline Comparing the cleaning process & 8 & 10.4 \\
Comparing the time resulted in tearing & 7 & 9.1 \\
Comparing the level of wetness & 6 & 7.8 \\
Choosing the durable one & 6 & 7.8 \\
Choosing the one that cleans a wet place better & 6 & 7.8 \\
Choosing the dry one after wetting them & 5 & 6.5 \\
Choosing the thicker one & 4 & 5.2 \\
Examining the two under a microscope & 4 & 5.2 \\
Examining their shapes & 4 & 5.2 \\
Choosing the wet one after wetting & 2 & 2.6 \\
\hline
\end{tabular}

In addition to the responses listed fon Table 10, there were unconventional responses such as 'burning them with a lighter', 'choosing the one made of pure cotton', 'observing the two after placing an ice cube on each', and 'choosing the more sun-resistant one'. Choosing the clean one, the most beautiful one, the most expensive one, the most convenient one were not counted as acceptable responses due to lack of relevance and clarity.

The scale development study by $\mathrm{Hu}$ and Adey (2002) was conducted on 12-15 year-old students, while the current study dealt with 7-9 year-olds. A comparison of the mean and standard deviation values by age is provided in Table 11 . Here, a clear pattern is observed, where mean scores increase as students get older. A further comparison was carried out for mean scores of 9 year-old and 12 year-old students. The mean score difference for these age groups was found to be less than eight points, which could be seen as relatively small compared to mean score differences for consecutive age groups.

Table 11. Comparisons of mean and standard deviation values by age across studies

\begin{tabular}{lccc}
\hline \multicolumn{1}{c}{ Studies } & Age & Mean & SD \\
\hline Hu \& Adey & 12 & 45.36 & 20.18 \\
& 13 & 56.92 & 21.25 \\
The current study & 15 & 62.52 & 23.45 \\
& 7 & 23.11 & \\
& 8 & 29.63 & 11.68 \\
& 9 & 37.65 & 10.86 \\
\hline
\end{tabular}

\section{Inferential Statistics}

Relevant statistical tests and findings will be presented in this section. Initially, Shapiro-Wilk test was run to test STC scores for normality. Data showed normal distribution $(p<0.05)$. Therefore, parametric tests were used in the analyses.

To test whether the level of scientific creativity differs with respect to grade level, oneway analysis of variance (ANOVA) test was used. Difference in the level of scientific creativity for several grade levels was found to be statistically significant at $95 \%$ confidence level $(F(2,82)=$ 11.877, $\mathrm{p}<0.05$ ). 
To compare the performances of students at different grade levels of STC, Scheffe Post-hoc test was used. Table 12 presents the post-hoc test results, which indicated that 4th grade students achieved significantly higher scores than their counterparts in 2nd and 3th grade (Table 12). While grade level produces a statistically significant difference in students' level of scientific creativity, such variables as gender, number of siblings, parental occupation, favorite subject, perception of the level of success at their favorite subject, and future occupation were not found to be statistically significant $(\mathrm{p}>0.05)$.

Table 12. Multiple comparisons of SCT score means by grade level

\begin{tabular}{|c|c|c|c|c|c|c|}
\hline \multirow[t]{2}{*}{ (I) grade } & \multirow[t]{2}{*}{ (J) grade } & \multirow{2}{*}{$\begin{array}{c}\text { Mean } \\
\text { Difference (I-J) }\end{array}$} & \multirow[t]{2}{*}{ Std. Error } & \multirow[t]{2}{*}{ Sig. } & \multicolumn{2}{|c|}{ 95\% Confidence Interval } \\
\hline & & & & & Lower Bound & Upper Bound \\
\hline \multirow{2}{*}{2} & 3 & -6.519 & 2.662 & .055 & -13.16 & .12 \\
\hline & 4 & $-14.536^{*}$ & 2.999 & $.000 *$ & -22.01 & -7.06 \\
\hline \multirow{2}{*}{3} & 2 & 6.519 & 2.662 & .055 & -.12 & 13.16 \\
\hline & 4 & $-8.017^{*}$ & 3.088 & $.039 *$ & -15.72 & -.32 \\
\hline \multirow{2}{*}{4} & 2 & $14.536^{*}$ & 2.999 & $.000^{*}$ & 7.06 & 22.01 \\
\hline & 3 & $8.017^{*}$ & 3.088 & $.039 *$ & .32 & 15.72 \\
\hline
\end{tabular}

\section{DISCUSSION and CONCLUSION}

Now that STEM education is of greater importance with the changing needs and skills required to help with the adjustment of the young generation to the $21^{\text {st }}$ century, there is a growing need for research to interpret STEM education. In the present study, a group of elementary students offered STEM classes for an entire academic year were examined for their level of scientific creativity, which implies innovation, imagination, scientific method, implementation, design, and products. Although this quantitative study is limited in sample size, it is expected to contribute to the literature with its focus on both STEM education and scientific creativity as well as the age group concerned and their length of exposure to STEM education.

Descriptive findings for students' favorite subjects, most successful subjects, and their willingness to make a STEM-related future career give important insights into the future tendencies of the sample. As elementary school students (aged 7 to 9), they expressed their interest and achievement in STEM subjects, and their willingness to work in a STEM field in the future. Within the sample, academic achievement did not show any variance since the current education system is concerned with maintaining student motivation rather than dealing with variety in and sequencing of achievement levels for younger students. Kılıç and Tezel (2012) studied eighth grade students whose science achievement scores varied widely. They found that those with higher science scores on their yearly report card were more likely to attain higher scientific creativity scores on SCT. In their study on eight graders, Ayverdi et al (2012) found a similar positive correlation between science achievement and scientific creativity scores. Findings point to the fact that a group of students had some negative experiences in their postprimary science classes, which seemed to inhibit their science performance and scientific creativity.

In the present study, it was found that there was a statistically significant difference between grade level and scientific creativity of participants. This finding is consistent with the relevant literature (Hu \& Adey, 2002; Lin et. al. 2003), where students' scientific creativity scores at older ages were found to be positively correlated with their scientific knowledge, experience, and skills. Hu and Adey (2002) maintain that the relationship between age and scientific creativity is not linear, since there are some other issues involved such as increased peer pressure and high-stake tests to be taken at certain time intervals (Ayverdi et. al. 2012).

Gender and scientific creativity have been investigated in a number of studies and it was concluded that there is not a statistically significant difference between gender and scientific 
creativity scores in the majority of cases (Kanlı, 2017; Özdemir \& Sak, 2013; Ayverdi et.al, 2012). Kılıç and Tezel (2012), however, reported a significantly higher scientific creativity mean scores for girls. Kanl (2017) strongly recommends that further research be conducted with diverse sample groups and instruments to study the issue of gender in scientific creativity. For the current study, no statistically significant gender difference was reported and the finding is consistent with the Equity principle presented in the Integrated Teaching Framework (Çorlu, 2017) where all subgroups are encouraged to express and benefit from their own experience of and interest in STEM classes.

Besides obtaining statistical data, the current study aimed at examining the content of student responses on STC by referring to the content and skills covered in the EarlySTEM Program. Question number 1 and 3 (Table 2) are a case in point as they encourage students to develop different uses of and modifications to everyday items. To be able to answer these questions, one needs to be creative and innovative. Although the terms 'creativity' and 'innovation' seem to be one of the main concerns of Primary School Curricula, there are not any activities available for students to develop new uses of materials or modify the tools in textbooks. However, in each EarlySTEM theme, the students were presented with several materials and were given options as to whether to choose or design their own tools to solve APKS.

Question number 2 required students to ask questions on travelling to outer space and it was the most frequently selected question with 172 responses. Although scientific terms like 'planet' and 'satellite' are not introduced in the curricula for corresponding grades, the students were able to ask various questions about living conditions in and physical features of Mars, satellites, and outer space. They were able to include scientific terminology such as galaxy, Milky Way, and Saturn's ring. Some of the student responses included mathematical content such as position in the space and dimensions of a planet. Questioning is a crucial science process skill and it is widely encouraged in the Fact-finding and Ideation phases of the STEM-cycline (Figure 2) in the EarlySTEM program.

A hypothetical situation was presented in Question number 4: What would happen if there was no gravitation on Earth? The students enrolled in the EarlySTEM program were familiar with hypothetical cases such as those presented in APKS. Moreover, the two EarlySTEM themes were on Mars, indicating that they had previous knowledge on a planet with less surface gravity than the Earth.

Question number 5, however, was a pure mathematics question on the different methods one can derive when dividing a square into four equal pieces. Deriving methods is a higherorder thinking skill. Here, nine students were able to derive four methods for the task while none of the students could go beyond the four methods. In their meta-analysis of STEM education research, Becker and Park (2011) identified mathematics as the discipline least favored for the implementation of integrative STEM approaches. A higher number of mathematical tasks should be introduced in the EarlySTEM program to nourish scientific creativity.

Question number 6 had to do with designing and testing an experiment. These high-level science process skills are not the main focus of the curricula for corresponding grades. However, these skills are viewed as steps crucial to Product Development and Refinement phases of the STEM-cycline (Figure 2). Most of the student responses included comparisons of at least two conditions, which implies that there is need for an experimental design to be developed for the given case (Table 10).

The final question on STC is a critical one in which students are required to draw a sketch of a hypothetical machine to pick up apples. For the students enrolled in the EarlySTEM program, drawing a sketch is a typical step to be taken in the Ideation phase of the STEM-cycline. In addition to drawing sketches, students were expected to generate as many functions of the hypothetical machine as possible.

In conclusion, the current study is not an experimental study where student performances are tested in the presence and absence of a STEM program. However, the content and the skills covered in the corresponding EarlySTEM program were found to be associated with the way scientific creativity components are addressed in the well-known Scientific Creativity Test as 
one independent of any STEM education interventions.

Sanders (2009) emphasizes the role of elementary school years in the implementation of integrative approaches that will nourish students' interest in STEM fields. In their meta-analysis, Becker and Park (2011) found that there are a fewer number of integrative STEM studies at elementary school level although these studies resulted in a relatively higher effect size than those conducted at higher grades. The present study could be regarded, with its contribution to the STEM education literature, as one that aims to associate STEM practices with scientific creativity for an under-represented sample, namely elementary school students. In future studies, research designs should include experimental groups and alternative instruments specifically designed to assess scientific creativity of the corresponding age group.

\section{Acknowledgements}

Data was collected as part of the Integrated Teacher Training Project (ITP) and the study was funded by Bahcesehir University STEM Center (BAUSTEM). Here, we would like to thank Assoc. Prof. Mehmet Sencer Çorlu for his invaluable support throughout the process.

\section{REFERENCES}

Aktamış, H., \& Ergin, Ö. (2006). Fen eğitimi ve yaratıcılık. Dokuz Eylül Üniversitesi Buca Eğitim Fakültesi Dergisi, 20, 77 83.

Aktamış, H., \& Ergin, Ö. (2007). Bilimsel süreç becerileri ile bilimsel yaratıcıllk arasındaki ilişkinin belirlenmesi. Hacettepe Üniversitesi Ĕ̆itim Fakültesi Dergisi, 33, 11-23.

Alexander, P.A. (1992). Domain knowledge: Evolving themes and emerging concerns. Educational Psychology, 27, 3351.

Amabile, T. M. (1987). The motivation to be creative. In S. Isaksen (Ed.), Frontiers in creativity: Beyond the basics (pp. 223-254). Buffalo, NY: Bearly Limited.

Aşık, G., Doğança Küçük, Z., Helvacı, B., \& Çorlu, M. S. (2017). Integrated teaching project: a sustainable approach to teacher education, Turkish Journal of Education, 6(4), 200-215.

Ayverdi, L., Asker, E., Öz Aydın, S., \& Sarıtaş, T. (2012). İlköğretim öğrencilerinin bilimsel yaratıcılıkları ile fen ve teknoloji dersi akademik bașarıları arasındaki ilișkinin belirlenmesi. Elementary Education Online, 11(3), 646-659.

Baer, J. (1998). The case for domain specificity of creativity. Creativity Research Journal, 11(2), 173-177.

Baran, E., Canbazoğlu-Bilici, S., ve Mesutoğlu, C. (2017). Fen, teknoloji, mühendislik ve matematik (FeTeMM) spotu geliştirme etkinliği. Journal of Inquiry Based Activities, 5(2), 60-69.

Baykal, A. (2008). Yaratıcılık için firsat ne kadar önemli? 1. Ulusal Eğitimde ve Psikolojide Ölçme ve Değerlendirme Kongresi, Ankara Üniversitesi, Eğitim Bilimleri Fakültesi. 14-16 Mayıs 2008.

Baysal, Z. N., Kaya, N. B., \& Üçüncü, G. (2013). İlkokul dördüncü sınıf öğrencilerinde bilimsel yaratıclık düzeyinin çeşitli değişkenler açısından incelenmesi. Journal of Educational Sciences, 38, 55-64.

Becker, K., \& Park, K. (2011). Effect of Integrative Approaches among Science, Technology, Engineering and Mathematics (STEM) Subjects on Students' Learning: A Preliminary Meta-Analysis. Journal of STEM Education: Innovations and Research, 12, 23-37.

Breiner, J. M., Harkness, S. S., Johnson, C. C., \& Koehler, C. M. (2012). What is STEM? A discussion about conceptions of STEM in education and partnerships. School Science and Mathematics, 112(1), 3-11.

Brody, L. (2006). Measuring the effectiveness of STEM talent initiatives for middle and high school students. Annual meeting of the National Academies Center for Education, Washington, DC.

Bybee, R. W. (2010). Advancing STEM education: A 2020 vision. Technology and Engineering Teacher, 70(1), 30-35.

Ceran, S. A., Güngören, S. C.., \& Boyacıoğlu, N. (2014). Determination of scientific crea-tivity levels of middle school students and perceptions through their teachers. European Journal of Research on Education, Special Issue Contemporary Studies in Education, 47-53.

Çeliker, H. D. \& Balım, A. G. (2012). Bilimsel yaratıcılık ölçeğinin Türkçeye uyarlama süreci ve değerlendirme ölçütleri. Uşak Üniversitesi Sosyal Bilimler Dergisi, 5(2), 1-21.

Çorlu, M. S. (2017). STEM: Bütünleşik öğretmenlik çerçevesi. Çorlu S. ve Çallı E. (Ed.). (2017). STEM Kuram ve Uygulamalarıyla Fen, Teknoloji, Mühendislik ve Matematik Eğitimi Öğretmenler için Temel Kılavuz. (pp.1-10) İstanbul: Pusula Yayıncılık.

Çorlu, M. S., Capraro, R. M., \& Çorlu, M. A. (2015). Investigating the mental readiness of pre-service teachers for integrated teaching. International Online Journal of Educational Sciences, 7(1), 17-28.

Demir, S. (2015). A study on the evaluation of scientific creativity among science teacher candidates. Research on Humanities and Social Sciences, 5(11), 101-103.

Doğança Küçük, Z. (ed.). (2017) STEM Program Kitabı- İlkokul Öğretmenleri için Hikaye ve Etkinlik Kitapları ile Uyumlu Program Kitabl. Pusula Press, Istanbul.

Feldman, D.H. (1994). Beyond universals in cognitive development. (2nd Ed.) Norwood, NJ: Ablex.

Han, K. S. (2000). Varieties of creativity: Investigating the domain-specifity of creativity in young children. Unpublished doctoral dissertation. University of Nebraska. 
Hiller, S. E. \& Kitsantas, A. (2016). The validation of the citizen science self-efficacy scale (CSSES). International Journal of Environmental and Science Education, 11(5), 543-558.

Hu, W., \& Adey, P. (2002). A scientific creativity test for secondary school students. International Journal of Science Education, 24(4), 389-404.

Kanlı, E. (2017). Üstün Yetenekli Öğrencilerin Bilimsel Yaratıcıllk Düzeyleri, Cinsiyet ve Bilimsel Tutumları Arasındaki İlişkilerin İncelenmesi. Elementary Education Online, 16(4), 1792-1802.

Kennedy, T. J. \& Odell, M. R. L. (2014). Engaging students in STEM education. Science Education International, 25(3), 246-258.

Kılıç, B. \& Tezel, Ö. (2012). İlköğretim sekizinci sınıf öğrencilerinin bilimsel yaratıcılık düzeylerinin belirlenmesi. Journal of Turkish Science Education, 9(4), 84-101.

Lin, C., Hu, W., Adey, P., \& Shen, J. (2003). The influence of CASE on scientific creativity. Research in Science Education, 33(2), 143-162.

MoNE. (2018). $\quad$ Primary School Curricula $30 \quad$ March 2019 Retrieved from http://mufredat.meb.gov.tr/ProgramDetay.aspx?PID=144

Özdemir, N. N., \& Sak, U. (2013). Bilimsel yaratıcıllk cinsiyet farklılıklarının bileșensel analizi [A componential analysis of gender differences in scientific creativity]. Turkish Journal of Giftedness and Education, 3, 53-65.

Pekmez, E. S., Aktamıs, H., \& Taskın, B. C. (2009). Exploring Scientific Creativity of 7th Grade Students. Journal of Qafqaz University, 26, 204-214.

Ricks, M. M. (2006). A study of the impact of an informal science education program on middle school students' science knowledge, science attitude, STEM high school and college course selections, and career decisions. (Unpublished doctoral dissertation). The University of Texas at Austin, Austin, Texas, USA.

Rinke, C. R., Gladstone-Brown, W., Kinlaw, C. R., \& Cappiello, J. (2016). Characterizing STEM Teacher Education: Affordances and Constraints of Explicit STEM Preparation for Elementary Teachers. School Science and Mathematics, 116(6), 300-309.

Roberts, L. (2003). Creativity. Tech Directions, 63(3), 12.

Runco, M. A. (1989). The creativity of children's art. Child Study Journal, 19, 177-189.

Sadler, P. M., Sonnert, G., Hazari, Z., \& Tai, R. (2012). Stability and volatility of STEM career interest in high school: A gender study. Science education, 96(3), 411-427.

Sanders, M. (2009). STEM, STEM education, STEMmania. The Technology Teacher, 68(4), 20-26.

Stohlmann, M., Moore, T. J., \& Roehrig, G. H. (2012). Considerations for Teaching Integrated STEM Education. Journal of Pre-College Engineering Education Research, 2(1), 28-34.

Torrance, E. P. (1990). Experiences in developing creativity measures: Insights, discoveries, decisions. Unpublished Manuscript, Torrance Center for Creative Studies and Talent Development, University of Georgia, Athens.

Tyson, W., Lee, R., Borman, K. M., \& Hanson, M. A. (2007). Science, technology, engineering, and mathematics (STEM) pathways: High school science and math coursework and postsecondary degree attainment. Journal of Education for Students Placed at Risk, 12, 243-270.

Ülger, K. (2014). The investigation of the students' creative thinking development. Education and Science, 39(175), 275-284.

Yavuz, S. \& Coşkun, E. A. (2008). Sınıf öğretmenliği öğrencilerinin eğitimde teknoloji kullanımına ilişkin tutum ve düşünceleri. Hacettepe Üniversitesi Eğitim Fakültesi Dergisi, 34(34), 276-286. 